\title{
心電計の発明者アイントホーフェン医師の共同研究者だった同医師の 子息が太平洋戦争下の東京で亡くなっていたことに関する考察
}

望月吉彦

芝浦スリーワンクリニック

心電図を学ぶ者で,「心電計の発明者」であり「アイントーベンの三角形」にも名を残しているオ ランダ人医師アイントホーフェンの名前を知らない方はいないと思う。アイントホーフェン医師 は，心電計の改良に関する重要な研究を子息とともに行っていた。 ノーベル賞の受賞講演でも， 子息との共同研究について言及している. その共同研究者だった子息は数奇な運命をたどり, 東 京で亡くなっている，本稿はそのアイントホーフェン医師の子息に関する論考である.

心電計はオランダ人医師 Willem Einthoven $(1860$ - 1927)が発明, 1903年に世界で初めて心電 図記録に成功した(図 1)。本稿では, Willem Einthovenは「ウィレム・アイントホーフェン」と 記す(呼称については文末の注 1 および注 2 を参照).

この心電図はオランダのライデンにある「ブールハーフェ博物館 Museum Boerhaave」に展示 されている. 同博物館を訪れた時に撮影した．基本的波形や記録用紙の方眼が今も変わらないこ

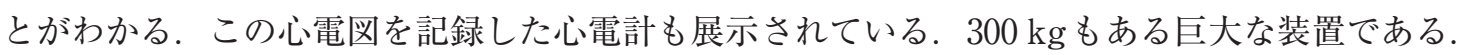

心電計は 100 年以上心疾患の診断に使われている希有な医療器械であり, その機能については 数多の研究がある. 筆者も心電計の機能に関してある発見をした．本稿を起こすに至ったのも， それがもととなっている，以下，簡単に紹介する。

胸壁の上に導電性のないポリエステルフィルムを貼り, その上に心電図電極を置くと心電図記 録はできない. 導電性がないからである. しかし, その導電性のないポリエステルフィルムの糊 面に「ヨードが含まれている」と，不思議なことに心電図が記録できる．ポリエステルフィルムの

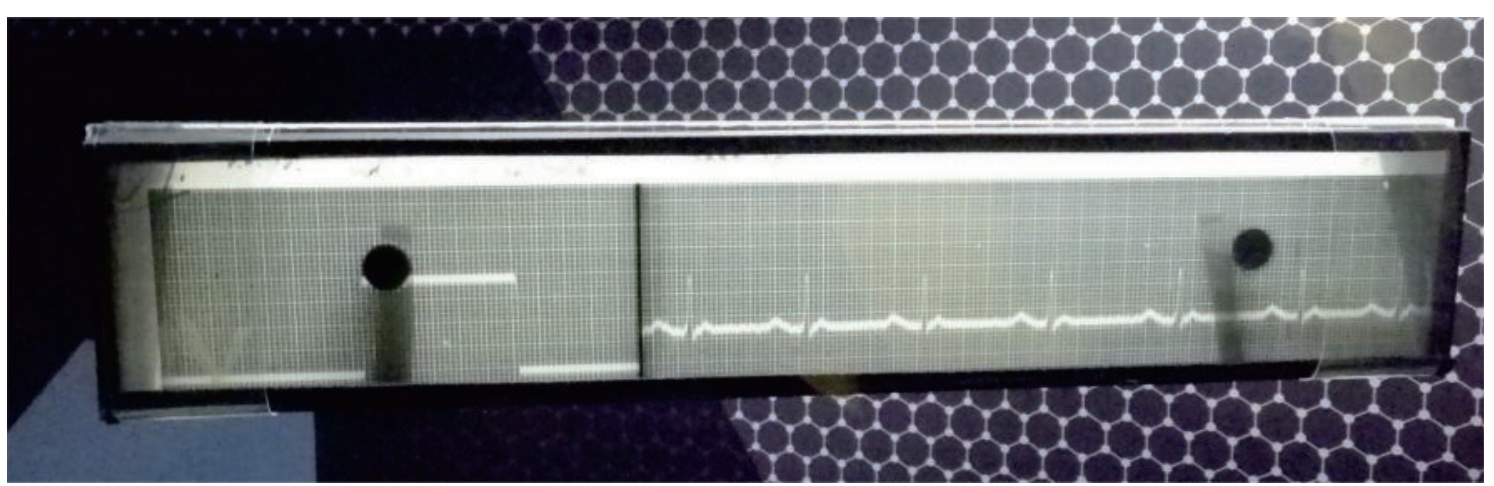

図 1 アイントホーフェン医師が世界で最初に発明した心電計で記録した心電図 


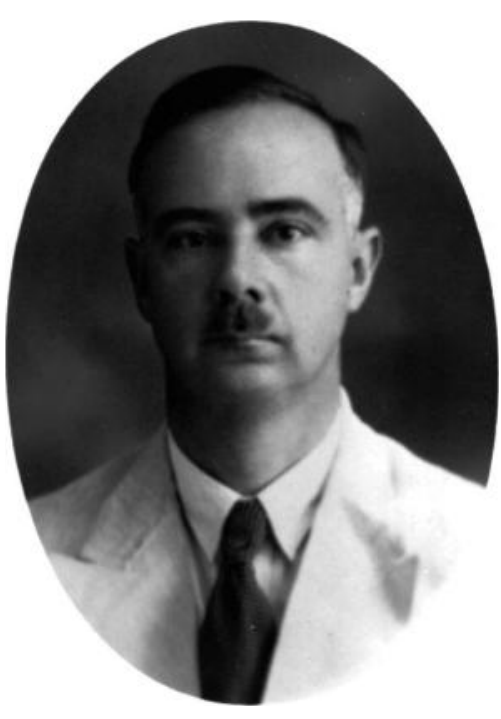

図 2

Willem Frederik Einthoven, Jr. の写真

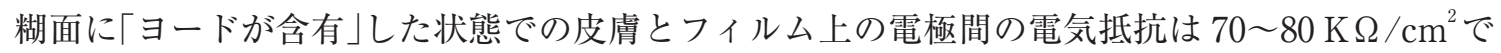
あり，フィルムがない(通常の心電図記録)状態での電気抵抗は $200 〜 300 \Omega / \mathrm{cm}^{2}$ だった。これだ け電気抵抗が違うのに, 記録される心電図の波形はほぼ変わりがない. とても興味深い現象であ ると考え，それを「The Annals of Thoracic Surgery」に投稿し，掲載された ${ }^{1)}$.

これを機に心電図の原理を学ぼうと思い,アイントホーフェンの著した心電図に関する論文を 収集した，彼は微分，積分，物理学を駆使して「心電計の原理」を考案している．彼は「弦検流計」 をもとに心電計を作っている.

弦検流計とは「強い磁場の中に金メッキを施した石英の弦を置き, その弦に電流が流れると弦 が動く，その動きの大きさを計測することで流れた電流を解析する」という原理の器械である. その弦検流計を用い, 生体内に生じている様々な電気信号の中から「心蔵から発する電気信号」だ けを取り出す器械が「心電計」で，それを記録したのが「心電図」である。私が発見した「電極と皮 膚の間の電気抵抗が大きく違っても心電図の記録に差がない」ことも,「心電計の原理」から説明 できることがわかった。

この心電計の原理について解説した文献や書籍は限られている. 日本では, 故 本橋均医師が 心電計の基本原理について解説した書籍を著している ${ }^{2)}$. 同書には心電計原理の解説のほかにも 多くの興味深いことが書かれていて, それが本稿を起こすもととなった. 同書より, 本稿と関係 する 4 点を挙げる.

1.アイントホーフェンには 4 人の子供がいた，男児は一人で, 長男のウィレム・フレデリック・ アイントホーフェン(Willem Frederik Einthoven, Jr.)である. 彼は電気工学者となり，父ととも に心電計の改良を行っていた(図 2)。(以下，本稿では心電計を発明したアイントホーフェンを “父アイントホーフェン”，長男のアイントホーフェンを“子アイントホーフェン”と略す)

2. アイントホーフェン「父子」が行った心電計に関する研究は, 弦検流計に用いる「弦」を真空中 
に置いて記録精度を高めるという研究だった。この研究はオランダの“軍事機密”とされ，その詳 細は明らかになっていないとあるが，これは間違いである．後述する.

3. 子アイントホーフェンは, 1927 年に父アイントホーフェンが亡くなった後, 当時オランダ領 だったインドネシアに赴き, インドネシア電電公社の所長になっていた.

4. 1941 年太平洋戦争が始まり, インドネシアで働いていた子アイントホーフェンは日本軍の俘 虜となり，1944年に東京に移送され，1945年 3 月の東京空襲で没したとある。「空襲で没した」 のは間違いである，後述する.

私はアイントホーフェン父子が行っていた弦検流計 ( = 心電計の原型)の改良, および「東京空 襲で没した」子アイントホーフェンについて興味をもった。

1944 1945年に子アイントホーフェンが東京で俘虜となっていたなら，その滞在中に医師の 診察を受けていたかもしれず, 医師なら「アイントホーフェン」という名前から, 父アイントホー フェンを想起しなかっただろうかと考えた。 日本に移送されたオランダ人俘虜について記されて いる資料を検索したが，なかなか発見できなかった。

先年, ようやく「子アイントホーフェンの東京抑留の事情, 東京抑留中の生活の様子」を詳述し た書籍等の資料があることがわかった。資料がなかなか見つけられなかった理由も，そのうちの 一冊に書かれていた。資料を列挙する。

1. 外国人抑留者に関する研究を長年行っている小宮まゆみ氏の著書 ${ }^{3)}$

2. 日本電気, 住友通信工業の資料 ${ }^{4)}$

3. 子アイントホーフェンの孫の著書「De Tempel met de Chrysanten : Krijgsgevangene in Tokio $\rfloor^{5)}$, 「The Temple with the Chrysanthemums Dutch Prisoners of War in Tokyo $\rfloor^{6}$ (いわ ゆる, 子アイントホーフェン一行の日本抑留記)

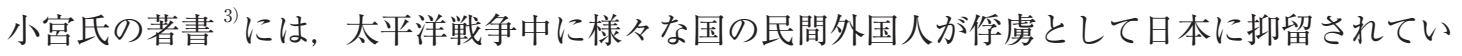
たことが記されている，同書によると外国人俘虜の中でもオランダ人俘虜については, なぜか厳 重に秘匿され, その資料を見つけるのは困難であったと記されている.オランダ人は特殊な事情 で日本に抑留されていたので, 戦後その関係の資料は簡単に閲覧できないようになっていたので ある. 特殊な事情については，後述する。

小宮氏が調査を進めたところ，外務省に「和蘭人(オランダ人)の抑留に関する件」という資料が 残っていることが判明, その中に子アイントホーフェン一行の日本抑留に関する記載があり, 氏 の著書で紹介している ${ }^{3)}$.

それによると，日本軍はインドネシアを占領後(インドネシアは当時オランダ領だった)，オラ ンダの高度な電気無線技術に目をつけ, インドネシア電電公社の所長だった子アイントホーフェ ン, その部下 4 名とその家族の計 22 名をインドネシアから東京まで移送, 彼らを東京都港区白 金にあった元チリ公使館に幽閉した．技術者 5 名は港区白金から神奈川県川崎市登戸まで毎日通 勤させ, 同所にあった研究所で仕事をさせていたのである. 子アイントホーフェンは肺炎が原因 
で死亡していたとの記録もあった，子アイントホーフェン氏が実際に日本に抑留されていたこ と，および同氏の死亡原因が，外務省に残っている公的文書で確かめられたのである.

子アイントホーフェンらオランダ人電気技術者たちに, 日本での「仕事」を命じていた日本電 気，住友通信工業側の記録を見つけることもできた ${ }^{4)}$.

小宮氏に，ほかにもこの件に関する資料がないか問い合わせたところ，子アイントホーフェン の孫「Ineke van der Wal」氏がいわゆる「子アイントホーフェン一行の日本抑留記」である「De Tempel met de Chrysanten : Krijgsgevangene in Tokio $\rfloor^{5)}$, 「The Temple with the Chrysanthemums Dutch Prisoners of War in Tokyo $\rfloor^{6}$ を2017年に出版したと教えられた(以下, Ineke van der Wal氏は“Ineke氏”と略す). 子アイントホーフェンとともにインドネシアから東 京に移送された同氏の夫人「Elisabeth Cornelia Zeeman (1895-1990)」氏が日本滞在中のことを 詳細に記録していて,その記録をもとに Ineke氏が「De Tempel met de Chrysanten : Krijgsgevangene in Tokio $\rfloor^{5)}$, 「The Temple with the Chrysanthemums Dutch Prisoners of War in Tokyo $\rfloor^{6}$ を出版していたのだ. 本書には, 父子アイントホーフェン一家のこと, 父子で 行った心電計改良のこと, 子アイントホーフェン一行の日本抑留中のことなどが詳細に記載され ている. 日本抑留関係については小宮氏の著書に引用されている外務省の記録と一致している. Ineke氏の著書 ${ }^{6}$ は358頁もあり, かなり詳細に書かれている. そのなかから, アイントホーフェ ン父子が行っていた心電計の改良に関すること, 日本抑留に関することを紹介する.

子アイントホーフェンは1893年オランダのライデンで生まれた. 小さい頃からカメラを自作 したほど機械に興味をもっていたとある。父アイントホーフェンの実験室にも出入りし，父アイ ントホーフェンの実験機械がどのように組み立てられているか, そして機械で使われているネジ がどのように作動しているかをよく理解していたとある．実験室の訪問者に「子供が実験室で何 をしているのか? 」と驚かれていたとも書かれている. 長じてデルフト工科大学で電気工学を学 び，卒業後は，父アイントホーフェンとともに心電計の改良に取り組んだ.

アイントホーフェン父子が行った心電計の改良点は, (1)心電計に使っていた「弦」をできるだけ 細くする, (2)その「弦」を真空中に封じ込める, の2点であることも同書でわかった. 父子は共同 して改良に努め,「真空弦検流計」を作り上げた。これにより，心電図の記録精度が高まった．「真 空弦検流計」の発明により，オランダ，ドイッ，カナダ，イギリス，アメリカ，そしてなんと日 本でも特許を取得したとある，筆者が特許を調べたところ, 子アイントホーフェンの名前で特許 を取得していることがわかった.「US Patent 1,592,628 on July 13, 1926 for a receiving wireless signal which was the basis behind his EKG machine monitoring.」とタイトルにあるようにここ の技術は $\mathrm{EKG}$ 記録がもとになっていたと思われる.

話は逸れるが, ライデン大学心臟病学の教授だったHerman Adrianus Snellen氏(1905 - 1998) の著書「Willem Einthoven $(1860$ - 1927) Father of electrocardiography : Life and work, ancestors and contemporaries 」)にも父子の共同研究について紹介され(p.50-51), 父子はこの「真 空弦検流計」に関する論文を書いていることもわかった ${ }^{8)}$. 9). 同書には父子がその実験室で一緒 に写っている写真も揭載されている (p.74). これらから類推するに, 本橋の著書 ${ }^{2}$ にある「真空弦 検流計は軍事機密」は間違いであろう. 
Ineke氏の著書 ${ }^{6}$ に戻る.「真空弦検流計」は心電図記録だけでなく無線通信にも応用され, 実 際，子アイントホーフェンは 1917 年にオランダからインドネシアに赴き，「インドネシアーオラ ンダ」間の無線通信実験を行ったとある.

1924 年, 父アイントホーフェンは心電計の発明によりノーベル生理学・医学賞を受賞. 筆者 がアイントホーフェンのノーベル賞の受賞講演を調ベたところ, その講演で「父子で共同開発を 行っている真空弦検流計」についても言及していることがわかった.ノーベル賞の受賞講演から 引用する ${ }^{10)}$.

"Engineer W. F. Einthoven has therefore made a model in which the string lies in a vacuum and this is specially suitable for the use of very thin strings.

We obtained with this model with a string about $2 \mathrm{~cm}$ long and $0.1-0.2 \mu$ thick and a magnification of the image of the string of 1800 times, a displacement of $1 \mathrm{~mm}$ in $0.01 \mathrm{sec}$ for a current of $10^{-11} \mathrm{~A}$."

下線で示した「Engineer W. F. Einthoven」は，本稿で論じている子アイントホーフェンのこと である，子アイントホーフェンが真空弦検流計を作り, 父子でそれをもとに実験を行い, 大きな 成果を得ていることを紹介している。 このことから, 子アイントホーフェンは心電計の創生期, その改良に大きな役割を果たしていたことがわかる。

Ineke氏の著書 ${ }^{6}$ に戻る. 1927 年父アイントホーフェンが死去, 子アイントホーフェンは心電 計に関わる研究を止め, インドネシアに赴いて, 同地のオランダ PTT (post telephone telegram：オランダ電電公社)に就職, 後にそのインドネシア所長に就任した.

子アイントホーフェンの電気技術に関する仕事は世界的に知られていて，その分野で国際的な 勲章も授与されている. 物理学者アインシュタイン博士から, 激励の手紙を貴ったとも書かれて いる.これらから, 彼は相当に優秀な電気技術者, 工学者だったと推察される.

1941 年 12 月 8 日に太平洋戦争が始まり, 日本軍はインドネシアに侵攻, 占領した. 当時イン ドネシアにいた 10 万人のオランダ人は, 軍人も民間人も, 全員日本軍の俘虜となった。インド ネシアにいた子アイントホーフェンとその部下も, もちろん俘虜になったが, 彼らはその技術力 を買われ，日本軍占領下でも占領前と同じ仕事を続けるように命じられていた．しかし，1942 年後半に, 日本から来た「Sumitomo company」の社員 3 人に業務を引き継ぐように命じられた. 彼らは英語を流暢に喋り, うち 1 人はハーバード大学出身と記されている. 業務の引き継ぎが終 わった 1943 年 11 月, 日本軍は子アイントホーフェン, 部下 4 名とその家族の計 22 名に対して, 日本に行くように命じた。一行は 1944 年 1 月 24 日にインドネシアを出発, 同年 3 月 28 日東京に 到着, 東京の芝区 (現 港区) 白金にあった元チリ公使館に幽閉させられた. 東京到着当初の 2 週 間は, 帝国ホテルから食事が届けられたとある. その後も, 彼らにはお手伝いや調理人がついて, それなりの待遇が供されていた，俘虜である以上，自由に暮らせるというわけではなかったが, 軍人の俘虜と異なり, 家族と一緒に住めるという稀な処遇だった.

東京到着後, 子アイントホーフェンの下に「Sumitomo company」の幹部社員が来て,「13日間 
連続して働いてもらう。14日目は休日だ」と告げた。「そのような労働はジュネーブ条約に反す る」と抗議したが, 認められなかった. 彼らは東京の白金から神奈川県川崎市生田にある「住友通 信工業」研究所に, 陸軍の兵士とともに通勤させられていた。一緒に通勤していた兵士は英語だ けでなく，オランダ語にも通じていることがわかり，滅多なことは喋ることができなかったとある.

明治大学平和教育登戸研究所資料館に, 太平洋戦争中に神奈川県川崎市登戸にあった軍関係の 研究所に関する研究資料「地域から追う登戸研究所」がある ${ }^{11)}$.

この資料に載っている地図に「日本電気/住友通信工業株式会社生田分所跡」と記された場所が ある. 日本電気は 1943 年(昭和 18 年)から 1945 年(昭和 20 年)まで「住友通信工業」という社名で あり, 子アイントホーフェン一行はここで働かせられていたのであろう. 彼らは研究所で, 毎日 「大学の数学教科書にあるような計算」をさせられていたとある. いったい, なぜインドネシアか ら日本にまで連行され，こんな計算をやらされているのか，まったく意味不明だったとも記され ている.

Ineke氏の著書 ${ }^{6)}$ に記載はないが，2001年にその事情はすでに明らかになっていた，当時，子 アイントホーフェンと一緒に抑留されていた Mrs. Paulien Greeven Lels氏(日本抑留時は10歳) が 2001年にオランダから来日，1944～1945年に登戸にあった住友通信工業研究所の所長だった 大沢寿一氏(面会時 90 歳) と面会し, 子アイントホーフェン一行が行っていた「仕事」が明らかに なったのだ. Mrs. Paulien Greeven Lels氏によると, 大沢氏からは「オランダ人俘虜はこの研究 所でレーダーの研究を行っていた」と伝えられたと記している ${ }^{12}$. 一一方, 大沢氏が書き残した資 料 ${ }^{4)}$ によると,「軍部からオランダ人を使ってレーダー開発をするように指示されたが, 大切な 研究を敵国人のオランダ人にさせるわけにはいかず，ただ計算をさせていた」とある.これがイ ンドネシアから東京まで連れてきて「大学生がするような計算」をさせていたのが実情だったのだ ろう。

Ineke氏の著書 ${ }^{6)}$ に戻る. 子アイントホーフェン一行は東京に到着後, 聖路加国際病院を受診 している. 彼らの担当は Dr. IKEDAであった. Dr. IKEDAの診察室には父アイントホーフェン の写真が掲げられていて, しかもその写真には, 父アイントホーフェンのサインが記されていた. Dr. IKEDAは子アイントホーフェンの名前を見て, 「アイントホーフェン医師と何か関係がある のか? 」と尋ねたとある.「アイントホーフェン」の名前から心電計で有名な父アイントホーフェ ンのことを想起した医師がいたのだ。「私は，その写真のアイントホーフェンの息子だ」と答える と, Dr. IKEDAは父アイントホーフェンに会ったことがあり，その際に父アイントホーフェン の肖像写真にサインをしてもらったこと, 父アイントホーフェンを大変尊敬していることを伝 え, 父アイントホーフェンのサインの下にサインをするように促し, 子アイントホーフェンはそ れに応じている. 期せずして, 戦時下の東京に父子アイントホーフェンのサインが揃ったことに なる.

Dr. IKEDA は子アイントホーフェン一行に「何か困ったことがあったら何時でも相談」するよ うに伝えている。 なお, 聖路加国際病院には 1933 年に心電計が導入されている ${ }^{13)}$.

Dr. IKEDAのことを調べたところ,「聖路加国際病院の 100 年 ${ }^{14)} に 1939$ 年同院に勤務してい た医師の名簿が載っており, その中に「第 2 内科医長 池田泰雄」の名があった. この池田泰雄医 


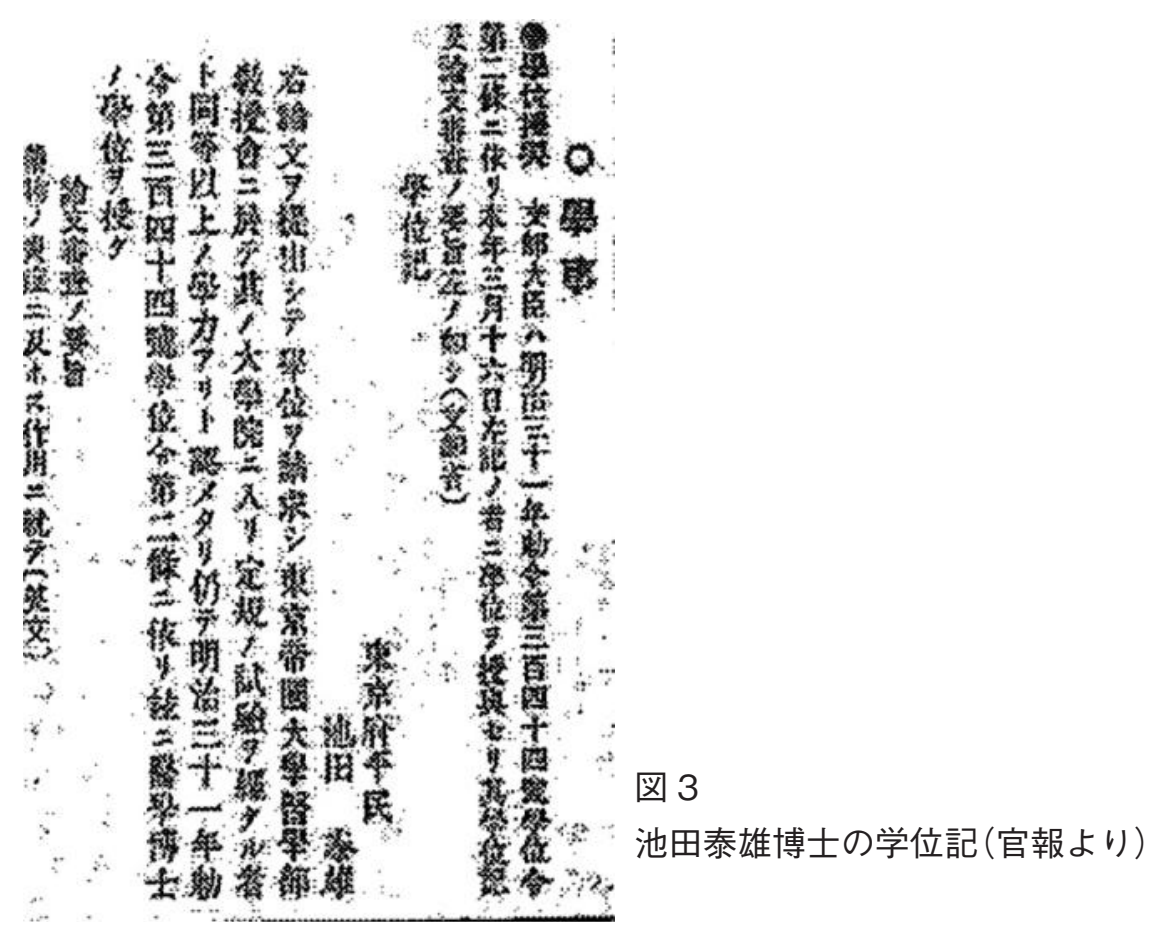

〔文献 15 より抜粋〕

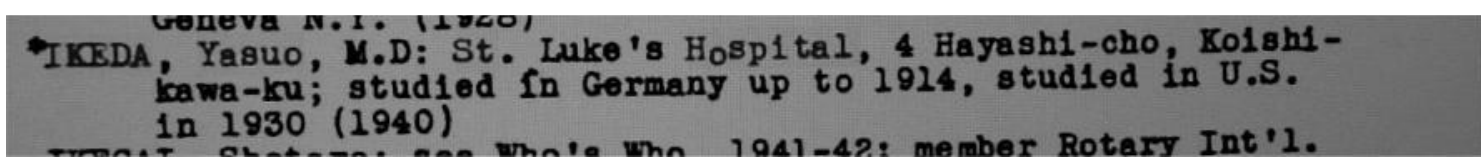

図 4 IKEDA Yasuo M.D.に関する記述

〔文献 16 より抜粋〕

師が子アイントホーフェンの診療に当たったDr. IKEDAだと推測し，経歴や論文を調べたとこ ろ，1898年東京帝国大学医学部から「池田泰雄」名で医学博士号が授与されていることがわかっ た．図3にその学位が記載されている官報 ${ }^{15}$ を示す。この学位記から察するに, 池田先生は東京 帝国大学医学部出身であろう。戦後, 米軍が作った資料 ${ }^{16)}$ のなかにも, 聖路加国際病院に勤務す る IKEDA Yasuoの名前を認める。「IKEDA Yasuo医師は 1914年までドイッに留学し，その後, アメリカでも学んだ」と記されている(図4).

残念ながら，これ以上のことはわからなかった。池田泰雄先生が, 父アイントホーフェンに面 会した時のこと，あるいは子アイントホーフェンを診察したことなどを書いた文献や記録があれ ばと思い探したが，そのような資料を見つけることはできなかった．父子アイントホーフェンの サインが入った肖像写真の行方にも興味があるが，こちらも不明である. 池田泰雄先生のことな ど，ご存じの方がいらっしゃればご教示いただければ幸いである.

Ineke氏の著書 ${ }^{6}$ に戻る．子アイントホーフェンが東京で亡くなった際の経緯についても, 詳

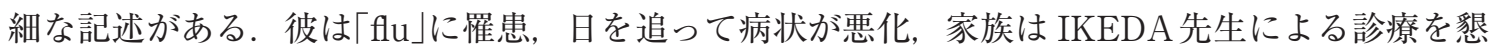
願したが, 折悪しくIKEDA先生も病いに伏せっていて願いは叶わなかった。病状は回復せず, 


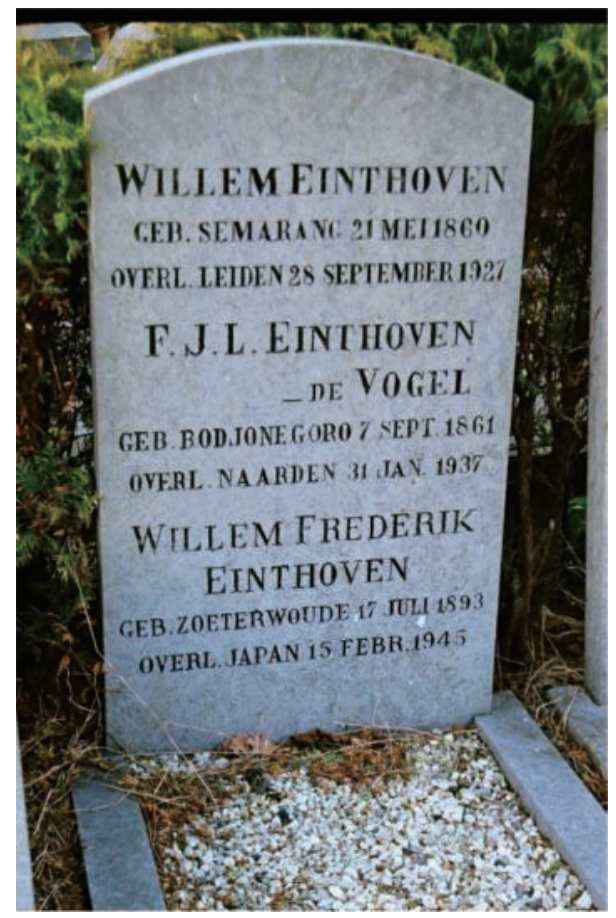

図 5

アイントホーフェン夫妻と子アイントホーフェン氏の 墓碑銘

最下段に「JAPAN 15 FEBR. 1945」の文字を認める.

1945年 2 月 15 日，インフルエンザによる肺炎のため，東京の滞在先で生涯を閉じた。享年 50 歳. 遺体は茶毘に付され，遺骨は戦後オランダに持ち帰られ，父母とともに埋葬されている(図 5).

総括

アイントホーフェン父子が「真空弦検流計」を作り, 心電計の精度を上げることに成功したこと や，子アイントホーフェン氏が東京で亡くなったことはあまり知られていないと思う。このよう なことに興味をもっていただければ幸いである。 な技, IKEDA医師が東京で, アイントホーフェ ンの名前から父アイントホーフェンを連想し, 子アイントホーフェン一行に対して, 親切に対応 してくれたことに少し「救い」を感じた。

最後に，子アイントホーフェン氏の消息についてご教示いただいた小宮まゆみ氏に感謝した い. 同氏の著書で太平洋戦争の最中，多くの民間外国人俘虜が日本で抑留されていたことを知っ た，歴史からほとんど忘れ去られているが，今一度，このような悲劇があったことを知ることも 大切だと思う。子アイントホーフェンをはじめ, 日本でお亡くなりになった多くの外国人俘虜の ことも忍びつつ, 稿を終えたい.

注 1 : Einthovenは英語の発音からきていると思われる「アイントーベン」と記されることも多くなっ ているが, Einthovenはオランダ人であり, オランダ語での発音「アイントホーフェン」を尊重すべきだ と考える。 な㧍, Einthovenは英語なら「エイントーヴン」「イーントーヴン」「イーイントーヴン」等と発 音されるのが自然であり，「アイントーベン」と記すのは二重の誤りだと指摘しておく.

注 2 : Einthoven's triangleは「アイントーベンの三角形」と称されることが多い.この三角形に関する 
Einthoven 自身の論文は 1913年に発表されている.

EINTHOVEN W, FAHR G, DE WAART A : Über die Richtung und die manifeste Grösse der Potentialschwankungen im menschlichen Herzen und über den Einfluss der Herzlage auf die Form des Elektrokardiogramms. Pflüger’s Archiv, $1913 ; 150$ : 275-315

“Pflüger’s Archiv”はドイツの雑誌であり，もともと本論文はドイツ語で書かれていたが，1950年に 英訳され, “American Heart Journal”に掲載された.

EINTHOVEN W, FAHR G, DE WAART A : On the direction and manifest size of the variations of potential in the human heart and on the influence of the position of the heart on the form of the electrocardiogram. Translated by Hebbel E. Hoff and Paul Sekelj. Am Heart J, 1950 : 40 (2) ; 163-211

英訳の方が多く読まれ，それが「アイントーベンの三角形」と呼称されるようになった一因であろう. なお，子アイントホーフェンは元論文が書かれた 1913 年には 20 歳で大学在学中であり，この論文には 関与していないと思われる.

注 3 ：図 2 および図 5はオランダの「War Graves Commission Oegstgeest」所蔵の写真である. 同委 員会から掲載許可を得ている。 この委員会は第二次世界大戦でお亡くなりになったオランダ人の生涯を 記録し追悼する組織で, 子アイントホーフェン氏の生涯についても紹介したサイトがある ${ }^{17)}$ 。なお，こ のサイトでは子アイントホーフェン氏の正式名称を「Ir. Willem Frederik Einthoven」と記している.「Ir.」 はオランダ語の「Ingenieur」の略で英語なら Engineerである.

\section{〔文献〕}

1) Mochizuki Y, Okamura Y, Iida H, et al. : Iodine-impregnated drapes enable recording of precordial electrocardiogram. Ann Thorac Surg, $1999 ; 67: 1184-1185$

2 ) 本橋均：絃の影を追って：W. Einthovenの業績, 初版. 医歯薬出版, 東京, 1969

3 ）小宮まゆみ：敵国人抑留：戦時下の外国民間人, 初版. 吉川弘文館, 東京, $2009 ; 173-176$

4) 日本電気株式会社編：日本電気ものがたり，初版. 日本電気，東京，1980；157

$5)$ Ineke van der Wal : De Tempel met de Chrysanten : Krijgsgevangene in Tokio, 1st ed. Independently published, Holland, 2017

6) Ineke van der Wal : The Temple with the Chrysanthemums Dutch Prisoners of War in Tokyo, 1st ed. Independently published, USA, 2017

7 ) Snellen, HA : Willem Einthoven (1860-1927) Father of electrocardiography : Life and work, ancestors and contemporaries. Springer, Netherlands, 1995

8 ) Einthoven Jr, WF : The string Galvanometer in wireless telegraphy. Proceedings, $1923 ; 26$ : numbers 7, 8.

9 ) Einthoven W, Einthoven WF, Willem van der Horst, et al. : Brownsche Bewegingen van een gespannen snaar. Physica, $1925 ; 5: 358-360$

10）ノーベル賞委員会：Willem Einthoven - Nobel Lecture - Nobel Prize. https://www.nobelprize.org/prizes/ medicine/1924/einthoven/lecture/ (2021年 2月閲覧)

11）明治大学平和教育登戸研究所資料館：地域から追う登戸研究所. https://www.meiji.ac.jp/noborito/ event/6t5h7p00000gn1xj-att/6t5h7p00000o50en.pdf (2021年 2月閲覧)

12）オランダ日本インドネシア対話の会：Deportation to Japan : Search for Clarity. https://sites.google.com/ site/dlgnji4nl/programmas/conf08/2gre-en (2021年 2 月閲覧) 
13）日野原重明：心電計の歩み，検査法の変遷 (Clinical Laboratory 編集委員会編)。診療新社, 大阪, $1982 ; 295$

14）聖路加国際病院 100年史編集委員会編：聖路加国際病院の 100 年．聖路加国際病院，東京， 2002

15）大蔵省印刷局編：官報 1921 年 08 月 27 日. 国立国会図書館デジタルコレクション

16) United States Department of the Army : Pamphlet - Dept. of the Army. Tokyo, $1949 ; 579$

17) War Graves Commission Oegstgeest (Oorlogsgravencomité Oegstgeest) : Comité Herdenken en Vieren Oegstgeest. https://www.oorlogsgravenoegstgeest.nl/en/resistance-fighters/einthoven-en(2021年 2 月閲覧) 